\title{
Determining ridge and runnel longshore migration rate using Spot imagery
}

\section{Mesure du déplacement des barres et baïnes parallèlement au trait de côte à l'aide de l'imagerie spatiale Spot}

\author{
Virginie Lafon ${ }^{\mathrm{a}}$, Hélène Dupuis ${ }^{\mathrm{a}, *}$, Hélène Howa ${ }^{\mathrm{b}}$, Jean-Marie Froidefond ${ }^{\mathrm{a}}$ \\ ${ }^{a}$ DGO, CNRS-UMR 5805 "EPOC", Université Bordeaux I, avenue des facultés, 33405 Talence cedex, France \\ ${ }^{\mathrm{b}}$ Université d'Angers, UFR Sciences, 2, boulevard Lavoisier, 49045 Angers cedex 1, France
}

Received 20 September 2001; received in revised form 15 April 2002; accepted 15 April 2002

\begin{abstract}
High-resolution colour satellite imagery is used to map the morphology and to determine the longshore movements of intertidal ridge and runnel systems that characterise the Atlantic southwest coast of France. A couple of Spot images recorded during the summer of 1989 are processed to extract accurate geographical maps of the coastline defined, in this study, as the level corresponding to the lowest astronomical tide. The coastline extraction method is based on a reflectance model, providing depth measurements that were calibrated in the field. This method enables us to map the coastline regardless of the tide level above the lowest astronomical tide at the moment of the image capture. As this model can be extrapolated to a large area when sea water is clear (considering a restricted range of suspended matter concentration) and bottom colour is homogeneous, the variability of both water turbidity and bottom colour have been analysed on the images. From the remotely sensed coastlines, a statistical analysis of ridge and runnel system length and longshore migration has been performed for a $35 \mathrm{~km}$ long coastline located to the north of the Arcachon lagoon inlet. It has been observed that, during the summer of 1989 characterised by fair weather conditions, the typical ridge and runnel morphology remains nearly conservative. Whereas the ridge and runnel mean wavelength remains constant during the summer between 435 and $430 \mathrm{~m}$, about $84 \%$ of the systems move southward at the mean rate of $2.4 \mathrm{~m} \mathrm{~d}^{-1}$. These results derived from Spot image analysis were validated by in situ topographic surveys undertaken during similar hydrodynamical conditions. (C) 2002 Ifremer/CNRS/IRD/Éditions scientifiques et médicales Elsevier SAS. All rights reserved.
\end{abstract}

\section{Résumé}

L'imagerie satellitaire à haute résolution spatiale est utilisée afin de caractériser la morphologie et les déplacements des systèmes de barre-baïne intertidales situés sur la côte sud-ouest de la France baignée par l'océan Atlantique. Deux images Spot, enregistrées durant l'été 1989, ont été analysées afin de cartographier précisément le trait de côte défini, dans cette étude, comme le lieu du zéro hydrographique. La méthode d'extraction du trait de côte est basée sur un modèle de réflectance calibré sur le terrain, qui met en relation la réflectance avec la profondeur. Cette méthode permet d'obtenir une cartographie du trait de côte, quelle que soit la hauteur d'eau au dessus du zéro hydrographique. Comme ce modèle peut être appliqué à un long linéaire côtier lorsque la turbidité de l'eau varie peu et que la couleur du fond est homogène, la variabilité de ces deux paramètres a été estimée sur les images. A partir des traits de côtes qui ont été extraits, la longueur des systèmes barres-baïnes ainsi que de leurs déplacements parallèlement au rivage ont été statistiquement analysés sur une portion de la côte girondine mesurant $35 \mathrm{~km}$ de long, située au nord de l'embouchure d'Arcachon. Durant l'été 1989, caractérisé par des conditions relativement calmes, la morphologie des barres-baïnes change très peu. Les systèmes de barres-baïnes ont une longueur d'onde moyenne comprise entre 430 et 435 m et environ $84 \%$ des systèmes se déplacent vers le sud à la vitesse moyenne de 2,4 m par jour. Ces

\footnotetext{
* Corresponding author.

E-mail address: dupuis@epoc.u-bordeaux.fr (H. Dupuis).
} 
résultats obtenus par analyse d'images Spot ont été validés par le suivi topographique d'une plage de la zone pendant des conditions hydrodynamiques identiques. () 2002 Ifremer/CNRS/IRD/Éditions scientifiques et médicales Elsevier SAS. Tous droits réservés.

Keywords: Remote sensing; Ocean colour; Coastline; Ridge and runnel movement; Aquitaine coast

Mots clés: Télédétection; Couleur de l'océan; Trait de côte; Déplacement des barres littorales; Côte aquitaine

\section{Introduction}

Many mesotidal and macrotidal sandy coasts exhibit rhythmic sedimentary features such as ridge and runnel systems (Short, 1991). Ridges refer to bars parallel or subparallel to the coast, separated from the beach by depressions called runnels. Ridges are generally $100 \mathrm{~m}$ long and a few tens of metres wide. Rip channels, running perpendicular to the shoreline, regularly interrupt them. Since ridge and runnel terminology was proposed by King and Williams in 1949, several formation hypotheses have been proposed (Lau and Travis, 1973; Dolan and Dean, 1985; Aagard, 1991; O'Hare and Huntley, 1994; Falqués et al., in press), whilst two major schools of thought classify ridges and runnels differently (Orford and Wright, 1978). According to the British point of view (King and Williams, 1949), ridges and runnels are found on coasts dominated by tides, at the extreme seaward limit of the swash zone. In this case, cross-shore movements of less than $1 \mathrm{~m} \mathrm{~d}^{-1}$ are observed. According to the American school of thought, ridges and runnels are observed whatever the tidal range and are the result of the nearshore adjustment of sediment excess to wave climate. Previous studies of the physical processes involved in ridge and runnel morphodynamics, crucial for coastal modelling improvement, are generally based on hydrodynamic measurements and cross-shore topographic profiles. For instance, the coupling between wave climate data and in situ profile surveys shows that during fair weather conditions, ridges move onshore (Owens and Frobel, 1977; Mulrennan, 1992). However, profile spacing is not suited to study ridge longshore migrations that would be better analysed by mapping their contour. The longshore extent of ridges and runnels, together with the large tidal range, enables one to map only two or three systems at the most during one low-tide stand by means of classical field methods. As a consequence, ridge longshore motions are often neglected.

An alternative to accurate, but spatially limited, in situ ridge mapping is high-resolution colour satellite remote sensing, which provides instantaneous images of areas of several hundreds of square kilometres, with a spatial resolution better than $40 \mathrm{~m}$. This technique is now currently used to analyse both coastal sandbank movement (Bullard, 1983; Lafon et al., 2000) and shoreline changes (Loubersac et al., 1988; De Lisle and Drapeau, 1994; Lafon, 1999). The ridge and runnel systems (with reference to the American school of thought) developed in the intertidal zone of the mesotidal SW French coast (Pedreros et al., 1996; Michel and Howa, 1999) appear distinctly on Spot images recorded during the clear seawater period (Fig. 1). The shore, composed of homogenous fine to medium quartz sands (Pedreros et al., 1996), is dominated by westerly winds and WNW waves generating a southward longshore drift of the order of $6.8 \times 10^{5} \mathrm{~m}^{3}$ year $^{-1}$ (Michel and Howa, 1994). This particular forcing favours, at least during summer, ridge and runnel system longshore motion, which has been observed at Truc Vert beach during 1999 summer (Fig. 1). Coastline surveys, realised twice a month from May 31, 1999, to September 9, 1999, show that the couple of mapped ridges moves in the longshore drift direction at the mean rate of $1.7 \mathrm{~m} \mathrm{~d}^{-1}$ for a mean significant wave of $1.3 \mathrm{~m}$ height and $7.2 \mathrm{~s}$ period (De Melo et al., 2001). The present paper assesses the ability of high-resolution multiband colour Spot imagery to map the contour of ridge and runnel systems. It first details a coastline extraction technique based on a reflectance model parameterised in the field. Then, this method is applied to two Spot images recorded during the summer of 1989 (July 29 at 11:02 AM and October 4 at 11:14 AM) with the aim firstly to determine the ridge and runnel length scale along the $35 \mathrm{~km}$ long shore situated to the north of the Arcachon inlet (Fig. 1), and secondly to derive ridge and runnel rate of migration during summer 1989.

\section{Method and measurements}

\subsection{Spot images atmospheric correction and georeferencing}

Spot images cover areas measuring $60 \mathrm{~km} \times 60 \mathrm{~km}$. Spot 1 scenes are composed of three channels, respectively recorded in the yellow-green wavelengths (XS1: $0.5-0.59 \mathrm{~nm}$ ), the red wavelengths (XS2: $0.61-0.69 \mathrm{~nm}$ ) and the next infrared wavelengths (XS3: $0.79-0.89 \mathrm{~nm}$ ). The Spot multiband pixel size is $20 \mathrm{~m} \times 20 \mathrm{~m}$.

Atmospheric correction of the Spot scenes has been performed to transform Spot numerical counts (NC) into Spot reflectances $(\rho)$, comparable to reflectance measured at ground level $(R)$. From Viollier et al. (1980):

$$
\rho=\frac{1}{t}\left(\rho^{*}-\rho_{\text {atm }}\right)
$$

where $t$ is the atmospheric transmittance, and $\rho_{\text {atm }}$, the atmospheric reflectance, is the sum of aerosol reflectance $\left(\rho_{\mathrm{a}}\right)$, Rayleigh reflectance and reflectance due to the cou- 


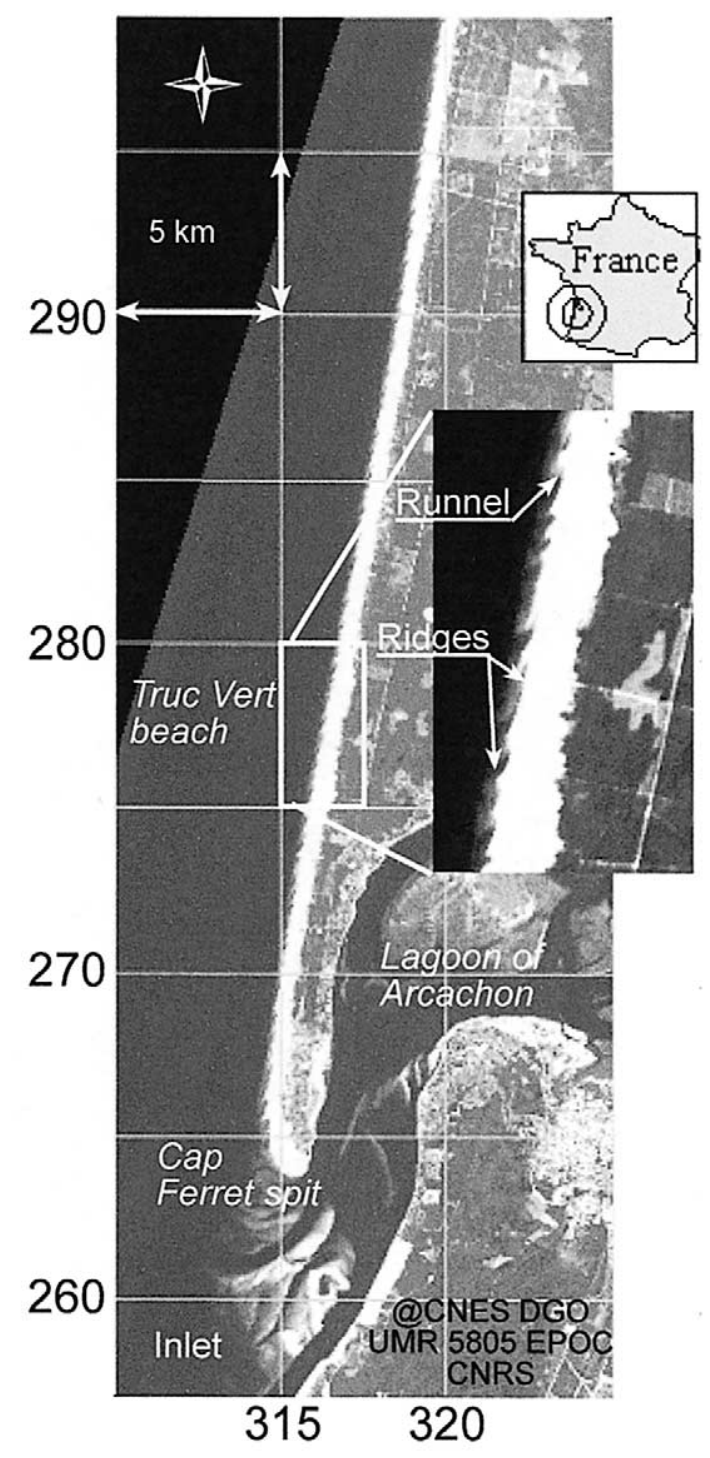

Fig. 1. XS1 Spot image of the studied site recorded on October 4, 1989, and georeferenced in the Lambert 3 French geographic system. This study concerns the coastline included between the longitudes of 264 and 299. The insert shows the ridge and runnel systems.

pling between aerosol and Rayleigh scattering. The reflectance at the top of the atmosphere, $\rho^{*}$, is obtained from the water leaving radiance $\left(L_{\mathrm{w}}\right)$ calculated by dividing NC by the absolute calibration gain (provided with Spot image), $\mu_{\mathrm{s}}$, the cosine of the solar zenith angle, and $E_{\mathrm{s}}$, the solar irradiance at the top of the atmosphere, which is computed with the second simulation of the satellite signal in the solar spectrum (6S), an atmospheric correction code (Vermote et al., 1997):

$$
\rho^{*}=\left(\pi L_{w}\right) /\left(\mu_{s} E_{s}\right)
$$

Whilst the term taking into account the coupling between aerosol and Rayleigh scattering is neglected by the $6 \mathrm{~S}$ simulation code, both the atmospheric transmittance and the Rayleigh reflectance are computed by $6 \mathrm{~S}$. To compute aerosol reflectance, information related to water and ozone concentration at the time of the image recording is necessary. As these data have not been recorded, an aerosol model adapted to each image has been determined. For this purpose, weak reflectance pixels in XS2 and XS3 wavebands are determined, which reflectance represents the atmospheric contribution only. From these values, the Angström number $(n)$, which governs the spectral variation of aerosol reflectance $\left(\rho_{\mathrm{a}}\right)$, is derived (Gordon and Clark, 1980):

$$
n=-\frac{\ln \left(\rho_{a 2} / \rho_{a 3}\right)}{\ln \left(\lambda_{2} / \lambda_{3}\right)}
$$

where $\rho_{\mathrm{a} 2}$ and $\rho_{\mathrm{a} 3}$ represent, respectively, aerosol reflectance at wavelength corresponding to XS2 and XS3. A marine aerosol model is chosen for $n$ lower than 0.4, a continental model for $n$ higher than 1.5 and a mixed model for $n$ ranging from about 0.4 to 1.5 (Lafon, 1999). In situ reflectances of the sand and water surfaces off the coast were used to validate the atmospheric correction results.

To provide cartographic results, a geometric correction has been applied to the images that have been resampled to the Lambert 3 French geographic system by Idrisi software. Image georeferencing was based on 67 and 65 control points, respectively, determined on IGN maps (scale 1:25 000), for July and October recordings. For both images, pixel location accuracy is better than 1.5 pixels (30 m). To resolve onshore motions of 10-30 m, observed during fair weather periods, it would be necessary to model the images by taking into account flight parameters. From the orbit model, the image is provided in any geographic projection system and is upgraded to an accurate cartographic product using a few calibration points. Indeed, simulating the flight characteristics will insure the correction of the marine area, which does not exhibit ground control points.

\subsection{Spatial coastline determination}

\subsubsection{Coastline definition}

To compare the ridge and runnel systems observed on the images and to measure their movement, it is necessary to map them at a precise reference level independent of tide level. The lowest astronomical tide (LAT) level, which systematically provides ridge and runnel shape, has been chosen to represent the coastline. The waterlines at 11:02 AM on 29 July, 1989, and at 11:14 AM on October 4, 1989, were respectively located 2.9 and $1.2 \mathrm{~m}$ above the LAT as calculated by the Service hydrographique et océanographique de la marine (copyright Shom, France, 2000). Although the ridges are partly submerged, they appear on Spot XS1 as shown in Fig. 1, due to water transparency. 


\subsubsection{Depth modelling}

Field studies of the moderately turbid tidal inlet of Arcachon (Fig. 1) allowed Lafon et al. (in press) to demonstrate that optic models adapted to coastal water type were able to retrieve shallow water bathymetry from XS1 shallow water reflectance. Hydrolight code (Lee et al., 1998) is expressed by the following equation:

$$
r_{r s}=r_{r s}^{D}\left[1-e^{-\left(K_{d}+K_{u}^{D}\right) z}\right]+\frac{1}{\pi} R_{r s}^{B} e^{-\left(K_{d}+K_{u}^{B}\right) z}
$$

where $r_{\text {rs }}$ represents the subsurface remote sensing reflectance (reflectance measured just below the water surface), $r_{r s}^{D}$ is the subsurface remote sensing reflectance of deep water, $z$ is the depth and $R_{r s}^{D}$ is the reflectance of the bottom that is assumed to be lambertian. $K_{\mathrm{d}}$ is the vertically averaged diffuse attenuation coefficient for downwelling irradiance. $K_{u}^{D}$ and $K_{u}^{B}$ are the vertically averaged diffuse attenuation coefficients for upwelling radiance measured, respectively, in deep and shallow water.

Subsurface remote sensing reflectance can be changed into the value of the above-seen surface remote sensing reflectance (Lee et al., 1998):

$$
R_{r s}(\lambda)=\frac{0.518 r_{r s}(\lambda)}{1-1.562 r_{r s}(\lambda)}
$$

As the reflectance above the sea water $\left(R_{\mathrm{rs}}\right)$ is also expressed by the ratio of water leaving radiance $\left(L_{\mathrm{w}}\right)$ to downwelling irradiance $\left(E_{\mathrm{d}}\right)$, it can be deduced that $R_{\mathrm{rs}}$ is proportional to Spot reflectance. Relation (4), calibrated with in situ values of deep water and bottom reflectance and of vertical attenuation coefficients, has been tested on the image recorded on October 4, 1989. In that case, it enables us to calculate depth in the inlet of the lagoon of Arcachon down to $6 \mathrm{~m}$ from XS1 Spot reflectance with an accuracy of $20 \%$, the water being clear and the bottom colour homogeneous. In situ reflectance data and Spot reflectance carried out from four images recorded in 1986, 1991, 1995 and 1997 have been used to compute depth from Eq. (4). In each case, the depth determination precision is always about $20 \%$, the range of total suspended matter concentration being included between about 0.2 and $10 \mathrm{mg} \mathrm{l}^{-1}$ (Lafon et al., in press). This means that the precision of depth determination depends partly on local weak turbidity variations. A part of this inaccuracy is due to the validation technique itself, which is based on the comparison of in situ surveys carried out at a precise location, with depth computation that represents averaged values for a pixel area $\left(400 \mathrm{~m}^{2}\right)$. This consideration is crucial when considering the accuracy of the geometric correction, which is about 1.5 pixels. Finally, it must be considered that sandbank movements may occur during the time elapsed between the recording of the Spot image and the corresponding recording of the hydrographic map.
To extend relation (4) to the images studied in this paper, the spatial homogeneity of bottom and water colour have been checked on the images on a large area covering the tidal inlet of Arcachon and the north coastline, following the method proposed by Lyzenga (1978).

\subsection{Reflectance and diffuse attenuation coefficient measurement}

Sand reflectance has been measured in the inlet of the lagoon of Arcachon on July 4, 1997, and at Truc Vert beach (Fig. 1) on May 25, 1998. Both these measurement sites are situated in the Spot observation area. In situ measurements have been carried out using a spectrophotometer Cimel, which provides three reflectance values corresponding to Spot channels. The Cimel reflectance $\left(R_{\mathrm{c}}\right)$ is obtained from the following relationship:

$$
R_{c}=L u /\left(E_{d} / \pi\right)
$$

where $E_{\mathrm{d}}$ is the downwelling irradiance. The Cimel has been calibrated to obtain a reflectance of $100 \%$ for a perfectly white target and $0 \%$ for a black target.

Dry and humid sands have been considered. Deep water reflectance has been carried out in the inlet of Arcachon lagoon. To determine precisely both sand and water reflectance, about 10 Cimel recordings of each substrate, respectively, have been carried out on each measurement site.

The vertically averaged diffuse attenuation coefficients for upwelling radiances $\left(K_{u}^{D}\right.$ and $\left.K_{u}^{B}\right)$ have been measured, respectively, in deep and shallow water according to the following procedure:

$$
K_{u}(\lambda)=-\frac{\ln L_{u 1}(\lambda)-\ln L_{u 2}(\lambda)}{z_{1}-z_{2}}
$$

where $L_{\mathrm{u} 1}$ represents upwelling radiance measured inside the water mass at depth $z_{1}$. Radiances have been recorded with an optical fibre linked to a high-resolution spectroradiometer (Spectron SE-590) that records visible and next infrared light. The value of $K_{\mathrm{d}}$ was approached by measuring the vertically averaged diffuse attenuation coefficients for upwelling radiances $\left(K_{\mathrm{L}}\right)$. Summing $K_{\mathrm{u}}$ and $K_{\mathrm{L}}$ allows calculating a value of the efficient attenuation coefficient $(K)$ adapted to an accurate determination of depth (Lafon et al., in press). Measurements have been made during the spring of 1997 and the summer of 1998. Total suspended matter concentration has been monitored simultaneously taking water samples $50 \mathrm{~cm}$ below the water surface. Samples were filtered (Whatman GF/F filters); filters were dried and weighted before and after filtration to obtain total suspended matter concentration. Results of these measurements are presented in the next section. 
Table 1

In situ reflectance of sand and deep water and effective attenuation coefficient $(K)$ according to total suspended matter concentration (SM) given in milligrams per litre

\begin{tabular}{|c|c|c|c|c|c|c|}
\hline \multirow[b]{2}{*}{ Spot channel } & \multicolumn{3}{|c|}{ Inlet of Arcachon } & \multicolumn{3}{|c|}{ Truc Vert beach } \\
\hline & XS1 & XS2 & XS3 & $\mathrm{XS} 1$ & XS2 & XS3 \\
\hline Dry sand reflectance $(\%)$ & $41.6 \pm 0.4$ & $48.6 \pm 0.4$ & $50.2 \pm 0.6$ & $39.6 \pm 1$ & $46.7 \pm 1.1$ & $50.5 \pm 1.3$ \\
\hline Humid sand reflectance $(\%)$ & $20.8 \pm 9.1$ & $27.0 \pm 9.9$ & $31.3 \pm 8.8$ & $24.4 \pm 2$ & $31.4 \pm 2.3$ & $33.3 \pm 2.5$ \\
\hline Deep water reflectance $(\%)$ & $1.83 \pm 0.47$ & $0.58 \pm 0.34$ & $0.17 \pm 0.12$ & & & \\
\hline$K\left(\mathrm{~m}^{-1}\right)(0.2 \leq \mathrm{SM} \leq 1.45)$ & 0.47 & 0.73 & & & & \\
\hline$K\left(\mathrm{~m}^{-1}\right)(7 \leq \mathrm{SM} \leq 9)$ & 0.52 & 0.97 & & & & \\
\hline
\end{tabular}

\section{Results}

\subsection{Parameterisation of depth determination model}

\subsubsection{In situ measurements}

The whole set of reflectance measurements is summarised in Table 1. It concerns the measurements carried out in the inlet of Arcachon (April 1997) and on the Truc Vert beach (May 1998) and provides mean sand and water reflectance values. Standard deviation of mean reflectance values has been added to show reflectance variability observed considering the whole set of measurements carried out at each measurement site. Table 1 shows that dry sand colour is homogeneous across the studied area. Variations appear when considering humid sand reflectance, which strongly changes with humidity, which was not measured simultaneously. However, humid sand reflectance is of the same order when considering both the measurement areas. Deep water reflectance obviously varies with total suspended matter concentration, which was included between 0.2 and $9 \mathrm{mg} \mathrm{l}^{-1}$. $K_{1}$ and $K_{2}$ are effective attenuation coefficients representing the sum of vertically averaged diffuse attenuation coefficient for upwelling and downwelling radiance in XS1 and XS2 waveband, respectively. It is observed that the ratio of $K_{2}$ to $K_{1}$, which can be seen as an index to characterise water colour (Lyzenga, 1978), ncreases with turbidity from 1.55 to $1.87 \mathrm{~m}^{-1}$.

\subsubsection{Atmospheric correction computation and validation}

The parameters used to force $6 \mathrm{~S}$ simulation code are reported in Table 2. The computed Angström number shows that, on July 29, the atmosphere had a complex aerosol composition, which has been determined to provide values of sand and aerosol reflectance close to the ones respectively measured in the field and on the Spot scenes. In contrast, the oceanic aerosol model is adapted to the correction of the image recorded on October 4. Obviously, the reflectance of humid sand and water pixels is comparable to that measured in the field, although water reflectance seems to be slightly lower. However, water pixels have been chosen off the coast, where suspended matter content is lower than that characterising the Arcachon inlet and the coastal zone. Furthermore, the sea bottom is closer to the water surface in the coastal area, which increases water surface reflectance also. Nevertheless, offshore deep water reflectance, particularly in XS3, proves the accuracy of atmospheric corrections. Decreasing optical depth would quickly increase XS3 water reflectance and, in proportion, slowly increase XS1 sand reflectance. Obtaining accurate parameters to force $6 \mathrm{~S}$ code, particular ozone and water concentration with altitude, is the key issue to better characterise spatial reflectance. However, both sand and water spatial reflectance are provided with an adequate accuracy as they approach in situ measurements.

\subsubsection{Analysis of homogeneity of sand colour on Spot scenes}

The colour of sand in the emerged area is analysed plotting XS1 reflectance versus XS2 reflectance of sand pixels randomly chosen in the whole studied area. Dots are aligned regardless of spatial and temporal sampling, which means that sand colour is homogeneous along the Gironde coast, an area that includes the inlet of Arcachon lagoon. XS1 and XS2 sand reflectance varies from $14 \%$ to $31 \%$, and from $16 \%$ to $36 \%$ respectively, which is of the same order as in situ data. In October (white squares), the range of value is larger than in July (dark circles), which means that sands may be brighter in October than in July. Atmospheric correction may be responsible for a larger attenuation of

Table 2

Atmospheric correction of images: implemented visibility, computed Angström coefficient $(n)$ and percentage of aerosols used (D, dust-like; W, water soluble; $\mathrm{O}$, oceanic). Humid sand and deep water reflectance demonstrate the validity of the atmospheric corrections

\begin{tabular}{|c|c|c|c|c|c|c|c|c|c|}
\hline \multirow[t]{2}{*}{ Date } & \multirow{2}{*}{$\begin{array}{l}\text { Visibility } \\
(\mathrm{km})\end{array}$} & \multirow{2}{*}{$\begin{array}{l}\text { Angström } \\
\text { number }\end{array}$} & \multirow{2}{*}{$\begin{array}{l}\text { Aerosol } \\
\text { model }\end{array}$} & \multicolumn{3}{|c|}{ Sand reflectance $(\%)$} & \multicolumn{3}{|c|}{ Water reflectance $(\%)$} \\
\hline & & & & XS1 & $\mathrm{XS} 2$ & XS3 & $\mathrm{XS} 1$ & XS2 & XS3 \\
\hline July 29, 1989 & 10 & 1.3 & $\begin{array}{l}40 \% \mathrm{D} \\
20 \% \mathrm{~W} \\
40 \% \mathrm{O}\end{array}$ & 15.9 & 19.7 & 24.6 & 1.36 & 0.32 & 0 \\
\hline October 4, 1989 & 34 & -0.23 & $100 \% \mathrm{O}$ & 14.9 & 19.3 & 30.5 & 1.22 & 0.15 & -0.02 \\
\hline
\end{tabular}


reflectance on July 29 , which is probably linked to the uncertainty of the aerosol model determination method.

\subsubsection{Analysis of shallow water colour homogeneity on Spot scenes}

To analyse shallow water colour homogeneity, the logarithm of the difference between shallow water XS2 reflectance and deep water XS2 reflectance is plotted versus the logarithm of the difference between shallow water XS1 reflectance and deep water XS1 reflectance. Regarding the scene recorded on July 29, 1989, and on October 4, 1989, dots form a line, the gradient of which, representing the ratio of $K_{2}$ to $K_{1}$ (Lyzenga, 1978), is nearly the same and is included in the range of gradients determined in the field. This signifies firstly that spatial turbidity variations are gentle considering one particular Spot scene, and secondly that the scenes exhibit relatively close turbidity conditions. The narrow gap that separates the lines indicates that sands are slightly darker in July, which confirms the very important attenuation of light by atmospheric corrections in the case of the image recorded in July.

As the test results show the global homogeneity of both sand and coastal water colours in an area including the inlet of Arcachon and the northern coast, the values used to parameterise the depth determination model and retrieve depth in the inlet are therefore adapted to extract the coastlines on both images. Therefore, the mean value of the effective attenuation coefficient $\left(K_{\mathrm{u}}+K_{\mathrm{L}}\right)$, that is $0.49 \mathrm{~m}^{-1}$ in XS1 waveband and $0.87 \mathrm{~m}^{-1}$ in XS2 waveband, should be used, whilst an XS1 sand reflectance of $22 \%$ clearly represents studied sand regardless of effects due to the modelling of light transfer through the atmosphere.

\subsection{Application to ridge and runnel morphology and longshore migration determination}

\subsubsection{System length}

On July 29, 1989, at 11:02 AM, the LAT was situated $2.9 \mathrm{~m}$ below the water surface, which corresponds to a Spot XS1 reflectance of 4.3\%. On October 4, 1989, at 11:14 AM, the LAT, situated $1.2 \mathrm{~m}$ below the water surface, corresponded to an XS1 reflectance of $7.6 \%$. Using these reflectance values, the location of the LAT level has been drawn on both images. As an example, a zoom of the coastline determined on the XS1 image recorded in September 1986 is shown in Fig. 2. The shapes of the ridge and runnel systems, smoothed to remove steppy pixel aspect, are clearly outlined and correspond very well to recent in situ observations of the Truc Vert beach made during the summer of 1999 (De Melo et al., 2001). The length of the ridge and runnel systems, as shown in Fig. 2, is defined as the distance between two rip channels considering their northern limit.

The system length characterisation for both scenes is detailed in Fig. 3, as frequency histograms. Regarding the whole studied site, 80 and 83 systems have been numbered,

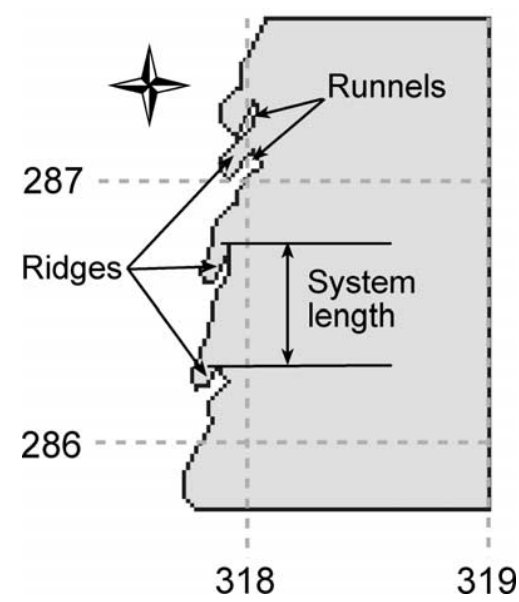

Fig. 2. Coastline derived from XS1 Spot image recorded on July 29, 1989 (Lambert 3 geographic coordinate system), and smoothed to remove the steppy pixel shape. Grey area represents the zone located above the lowest astronomical tide.

respectively, on July 29 and October 4 . Their mean size is, respectively, $435 \mathrm{~m}$, with a standard deviation of $211 \mathrm{~m}$, and $430 \mathrm{~m}$, with a standard deviation of $203 \mathrm{~m}$, which is of the same magnitude as field measurements. The smallest and the largest systems are, respectively, about 142 and $1480 \mathrm{~m}$. Less than $5 \%$ of the systems are smaller than $250 \mathrm{~m}$ or larger than $800 \mathrm{~m}$. The size distribution is negatively skewed both in July (Fig. 3, upper graph) and in October 1989 (Fig. 3, lower graph). The system length variability shows the difficulty in modelling the rhythmicity of the sedimentary unit pattern from small scale measurements. Such a periodicity has been explained, for example, by the presence at the coast of infragravity edge waves (Short, 1991; O'Hare and Huntley, 1994). But in our case, the system length variability indicates the influence of external conditions. Indeed, along the studied coast, the presence of nearshore crescentic bars $400 \mathrm{~m}$ off the coastline (Froidefond et al., 1990) is able to modify the distribution of incident waves at the coast and then to influence ridge and runnel formation. These preliminary results show that Spot images are suited to measure the length scale of the ridge and runnel systems. The next section examines if further information can be obtained from these coastlines, such as longshore migration.

\subsubsection{Ridge longshore movement}

In Fig. 4, a part of the coastline is displayed, the latitude of which is included between $269^{\circ}$ and $280^{\circ} \mathrm{N}$. Coastlines derived from XS1 images recorded in July (light grey) and in September (dark grey) have been displaced in longitude for an easier assessment of the movement in the longshore direction. Obviously, the ridge shape remains nearly unchanged during the summer. From July 29, 1989, to October 4, 1989, the height and period of waves were measured by the wave-gauge of Biscarosse, located about $10 \mathrm{~km}$ to the south of the inlet of Arcachon lagoon, where depth is $25 \mathrm{~m}$. Significant wave height $\left(H_{\text {sig }}\right)$ and period data calculated 

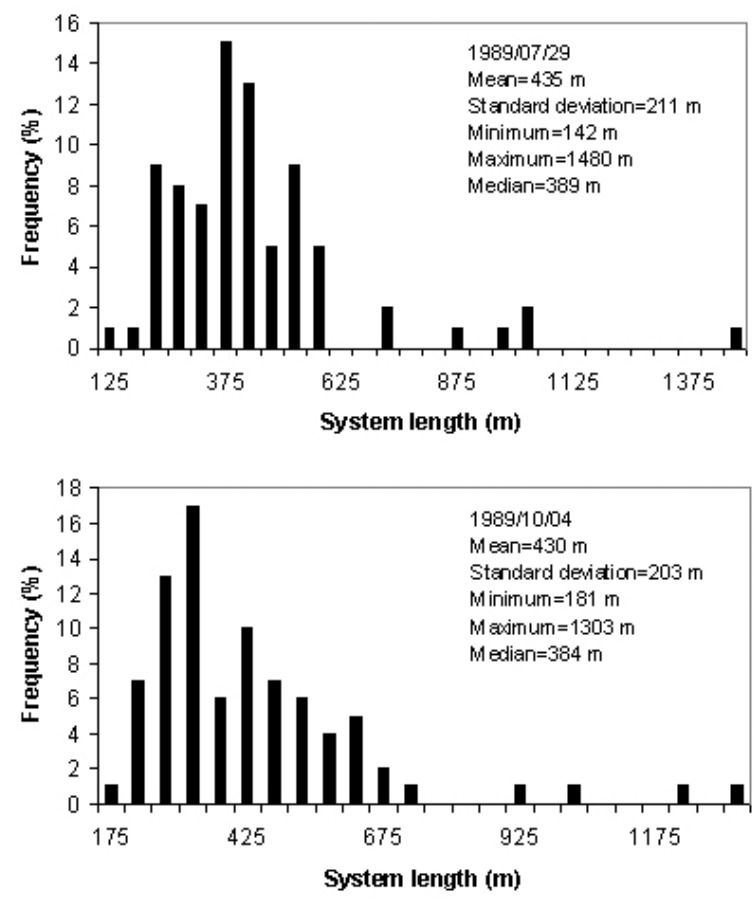

Fig. 3. Frequency histograms showing ridge and runnel size repartition regarding remotely sensed coastlines of the entire studied site. Results of the statistical analysis are indicated for Spot scenes recorded in July (upper graph) and in October (lower graph).

regularly every $3 \mathrm{~h}$ are provided by Météo-France. $H_{\text {sig }}$ ranges from 0.3 to $3.3 \mathrm{~m}$, with a mean significant wave height of about $1.05 \mathrm{~m}$ and a mean significant wave period of about $7.9 \mathrm{~s}$. Wave repartition clearly shows the large dominance of calm swell conditions (Fig. 5). The highest waves (from 2 to $3 \mathrm{~m}$ ) were observed over $21 \mathrm{~h}$ only. During the same period, wind blew mainly from the west-northwest (Fig. 6) with moderate speed. Hence, neither swells nor wind data evidence storm activity capable of destroying coastal bars. This calm climate confirms the preservation of ridges and runnels during 1989 summer that has been assumed from spatial coastline comparison.

The ridge morphologic conservation allows us to determine the system migration rate. From $270.7^{\circ}$ to $273.1^{\circ} \mathrm{N}$ and from $275.5^{\circ}$ to $280^{\circ} \mathrm{N}$, a general southward shift of the ridges is observed and measured considering the motion of the south boundary of a given ridge (Fig. 4, a and b). Few morphological changes are noted; however, at the latitude of $275^{\circ} \mathrm{N}$, a new ridge has formed (Fig. 4). Finally, from $269.6^{\circ} \mathrm{N}$ to $270.2^{\circ} \mathrm{N}$ (Fig. 4, c) and around $273.5^{\circ} \mathrm{N}$ (Fig. 4 , d), coastline shape is conserved. Regarding the whole studied site, amongst the 81 systems defined on July 29, 1989, 68 systems are clearly identified by their morphology on October 4, 1989. About $84 \%$ of the recognised systems move southward by an average of $161 \mathrm{~m}$ with a standard deviation of $138 \mathrm{~m}$, which represents a mean daily migration of $2.4 \mathrm{~m}$. About $12 \%$ of the systems seem to remain at the same place, whilst the remaining $4 \%$ move northward by 40-70 m during the time elapsed between the Spot record-

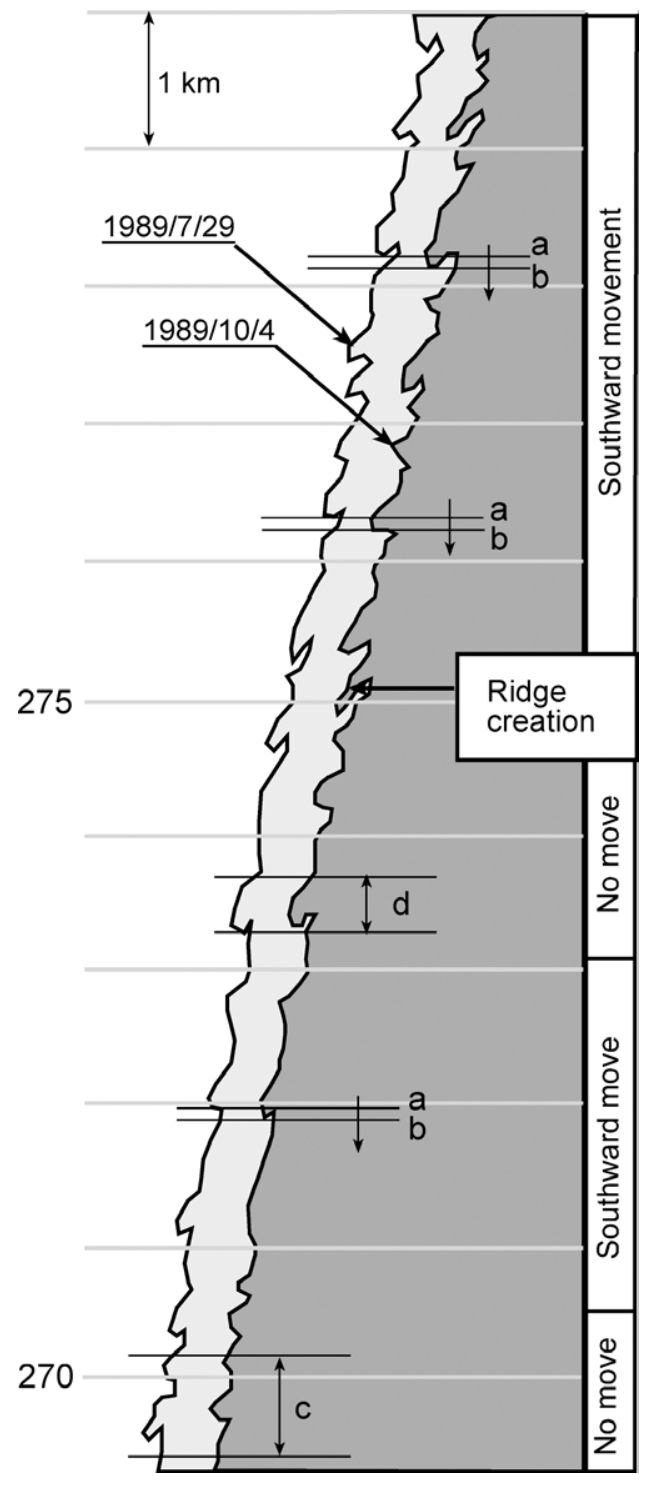

Fig. 4. Comparison between the coastlines derived from Spot images recorded in July (light grey) and in October (dark grey). For longshore movement analysis (in the kilometric Lambert 3 coordinate system), the coastlines have been set apart in the cross-shore direction. Notations show features of particular interest: ' $a$ ' and ' $b$ ' indicate the southward motion of three particular ridges; 'c' and 'd' localise area of null movement. A ridge creation is also indicated.

ings. Mean southward ridge migration is therefore $2.4 \mathrm{~m} \mathrm{~d}^{-1}$.

These results are compared to the recent in situ measurements carried out during 1999 summer on Truc Vert beach, situated in the Spot observation area. De Melo et al. (2001) report that coastline surveys, realised twice a month from May 31, 1999, to September 13, 1999, by mean of a differential global positioning system going along the waterline at low spring tide to approach the LAT, show that the couple of mapped ridges move in the longshore drift direction at the mean rate of $1.7 \mathrm{~m} \mathrm{~d}^{-1}$ for mean significant wave of $1.3 \mathrm{~m}$ height and $7.2 \mathrm{~s}$ period. Swell conditions recorded during the summers of 1989 (mean significant wave height of $1.05 \mathrm{~m}$ and mean significant wave period of 


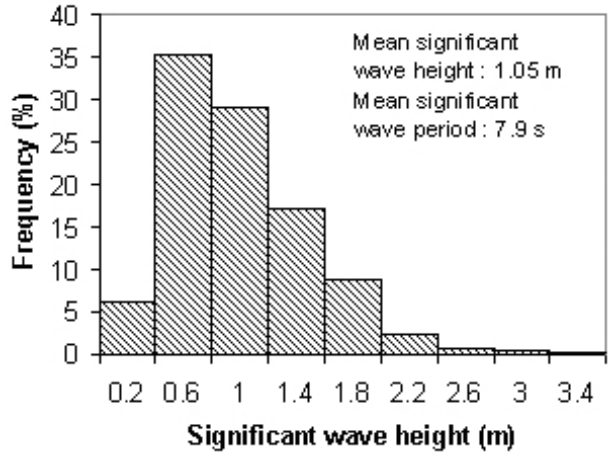

Fig. 5. Significant wave height frequency as recorded by a wave-gauge located a few kilometres to the south of the studied area.

about $7.9 \mathrm{~s}$ ) and 1999 are therefore relatively similar, and result in an intertidal rhythmic pattern southward migration rate of the same range. Indeed, this comparison validates Spot observation and the spatial coastline extraction technique when the sea water is clear. It also demonstrates that Spot sampling capabilities are adapted to the quantitative survey of ridge and runnel system movements in the longshore direction for fair weather conditions. Finally, this comparison allows us to extend in situ local but accurate observation to the $35 \mathrm{~m}$ long coastline situated to the north of the Arcachon inlet.

\section{Discussion}

These results demonstrate that Spot spatial maps display enough information to measure the longshore movements of sedimentary rhythmic features for fair weather conditions. However, several methodological and technical details need to be discussed with the aim of improving these results. For this purpose, imagery strategies are proposed.

The bathymetric model used is valid for water depths less than $6 \mathrm{~m}$, which is larger than the maximum tidal range of the studied site (Michel and Howa, 1994). XS1 therefore allows us to derive a coastline configuration under any tidal

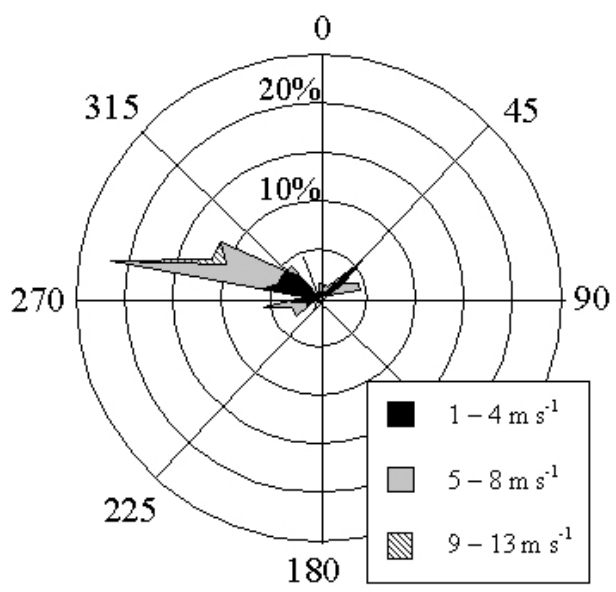

Fig. 6. Wind frequency according to wind direction and speed as recorded at Arcachon. conditions. Bottom colour homogeneity being demonstrated, turbidity must be checked before extracting the coastline and should correspond to the range in which the relationship has been validated both from space and in the field. Regardless of the relative homogeneity of turbidity, its weak variations are partly responsible for the accuracy of depth determination, which is about 20\% (Lafon et al., in press). This uncertainty in the location of the coastline, on the vertical axis, induces an error in the horizontal location, which is inversely proportional to the ridge slope. The minimum slope of the south part of the ridges in the longshore direction, as measured on the images, is $0.4^{\circ}$ (elevation of $0.5 \mathrm{~m}$ over a distance of $75 \mathrm{~m}$ ). Therefore, for water levels above the LAT of 1.2 and $2.9 \mathrm{~m}$, the coastline is drawn, respectively, with a vertical accuracy of 0.24 and $0.58 \mathrm{~m}$ and a horizontal accuracy of about 36 and $87 \mathrm{~m}$ in the ridge elongation direction. As the ridges are elongated at an angle of $20^{\circ}$ to the shoreline, the horizontal accuracy in the longshore direction is, respectively, $34 \mathrm{~m}(36 \times \cos 20)$ and $82 \mathrm{~m}(87 \times \cos 20)$. Coupling these errors leads to a maximum error of $116 \mathrm{~m}$ in distance. However, the migration rate has been computed using 68 systems. Therefore, considering that errors in distance are randomly distributed and independent, the uncertainty in the overall migration is finally $14 \mathrm{~m}(116 / \sqrt{68})$, and consequently $9 \%(14 / 161)$, the mean southward migration measured on the couple of images being of $161 \mathrm{~m}$. The georeferencing error $(30 \mathrm{~m})$ also induces a positioning error of the coastline of about $19 \%(30 / 161)$. At last, considering that LAT is given with a vertical accuracy of $20 \mathrm{~cm}$ leads to a coastline location error of $27 \mathrm{~m}$ or of $17 \%$ (27/161). Thus, the maximum error in the global migration rate is $45 \%$, which validates the southward motion of the systems during the summer. In the future, this accuracy will be improved by ensuring the georeferencing or the depth determination using, for example, better parameters to force the bathymetric model.

It must also be considered that Spot sampling capabilities limit the coastal geomorphology applications sometimes. Spot pixel size reduces the possibilities to compute small displacements. For example, obtaining images with a better spatial resolution would favour the survey of small crossshore movement, necessary to achieve complete coastal sandbank morphodynamics assessment. New optic sensors with a higher spatial resolution (Ikonos, Landsat and future Spot 5) are better suited for this purpose, and should emphasise their utility for sedimentary applications. For the study of morphological events occurring during a shorter period of time, it is necessary to increase the mapping temporal resolution. This will allow us, for example, to correlate the bar morphodynamics to hydrodynamic data in any meteorological conditions, which is valuable for coastal modelling. However, when the sky is cloudy, optic sensors become useless, which reduces the mapping frequency. Flying satellites under the control of meteorological data, which is the solution proposed for image programming, and 
radar techniques are two alternatives to increase the spatial data set.

Finally, in strong wave breaking conditions, the amount of sand in suspension prevents the use of the bathymetric model to determine the water depth. Nevertheless, in the case of the southwestern French coast, if the image is recorded at low spring tide, the waterline nearly reaches the LAT. Then, even if the breakers bound the shoreline, the coastline appears on XS3 Spot image, water having lower $\mathrm{XS} 3$ reflectance than sand.

\section{Conclusion}

This paper shows that high-resolution Spot imagery enables the mapping of coastlines that have a complex topography, composed of ridges and runnels. Furthermore, the comparison of coastlines mapped with the sampling capacities of the Spot satellite proves the migration of ridge and runnel systems in the longshore direction and gives the right order of magnitude. The XS1 images of two Spot scenes recorded during 1989 summer have been processed to determine the shallow water bathymetry and then derive the coastline at the LAT, a reference level independent of tide level. The ridges are elongated toward the southsouthwest. The mean wavelength of the ridge and runnel systems ranges from 430 to $435 \mathrm{~m}$. From the remotely sensed coastline superposition, the shoreline morphological changes are observed and measured. About $83 \%$ of the systems keep the same shape during the summer, amongst which $84 \%$ move southward by $2.4 \mathrm{~m} \mathrm{~d}^{-1}$ as a mean value. Compiling both northward and southward motions, the mean daily system migration rate is of $2.4 \mathrm{~m}$, which shows the weak influence of northward motions on the net sediment budget. This particular sedimentary behaviour characterises summer months, when fair northwesterly winds and waves dominate. In this case, both the shape and the bar migration indicate the dominance of the southward longshore drift on sediment dynamics in the intertidal zone. Therefore, if edge waves are responsible for the ridge or rip spacing regularity (Lau and Travis, 1973; Aagard, 1991; Short, 1991; O'Hare and Huntley, 1994), the longshore sediment transport modulates the geographic position of this rhythmic sedimentary pattern with time.

In situ mapping of ridge and runnel showing migration rate of the same order as Spot measurements, other pairs of images representing various climate conditions must now be investigated to improve knowledge about coastal morphodynamics. Furthermore, as Spot colour imagery reveals the presence of crescentic bars off the southwest French coast, their size and longshore and cross-shore movements will be measured. Further tests will be also performed regarding morphologic and morphodynamic links between intertidal and submarine bars. Besides, actual remote sensing technique evolution favours the generalisation of remote sensing use to better know the sediment transport in the nearshore zone. For example, merging Spot and Synthetic aperture radar images enables modelling of the influences that changing currents and wave patterns can have on multi-bar beaches. Indeed, shallow water bathymetry can be obtained regardless of the cloud cover and, henceforth, more regularly, by using airborne sensors. In several ways, they may also improve the results obtained by processing Spot imagery. For example, the hyperspectral Compact airborne spectrographic imager permits us to choose the most efficient wavelength to apply bathymetric models, analysing at the same time water content (George, 1997; Bagheri et al., 1998). This allows increasing depth determination accuracy. Also, to extract greater water depths, airborne lasers (such as light detection and ranging) seem to give good results down to two to three times the Secchi depth at $532 \mathrm{~nm}$ (Lyllicrop and Estep, 1995). Finally, regarding emerged areas, their cross-shore and longshore movements may be obtained with NASA's Airborne Topographic Mapper, a remote sensing laser technique, which determines the beach 3D topography (Krabill et al., 2000).

\section{Acknowledgements}

This study was funded by the Centre national d'études spatiales. The authors wish to thank the Laboratoire de biologie marine of Arcachon that helped us with field data collection in the inlet of Arcachon, and Météo-France, who provided us with wind and wave in situ measurements. Finally, the Service hydrographique de la Marine (Shom) is thanked for providing us with water level computation at the time of Spot image capture.

\section{References}

Aagard, T., 1991. Multiple-bar morphodynamics and its relation to lowfrequency edge waves. J. Coastal Res. 7, 801-813.

Bullard, R.K., 1983. Detection of marine contours from LANDSAT film and tape. In: Cracknell, A.P. (Ed.), Remote Sensing Applications in Marine Science and Technology. D. Reidel Publishing Company, Holland, pp. 373-381.

De Lisle, D.A., Drapeau, G., 1994. Coastline and nearshore features delineation using remote sensing. WMO/IOC Technical Conference on Space Based Ocean Observations. World Meteorological Organization and Intergovernmental Oceanographic Commission of UNESCO. pp. 992-1004.

De Melo Apoluceno, D., Howa, H., Oggian, G., 2001. Systèmes de barres-baïnes du Truc Vert, Littoral Aquitain. XXVI Colloque de l'U.O.F. La Rochelle, France.

Dolan, T.J., Dean, R.G., 1985. Multiple longshore sand bars in the upper Chesapeake Bay. Estuarine Coastal Shelf Sci. 21, 727-743.

Falqués, A., Coco, G., Huntley, D.A., in press. A mechanism for the generation of wave driven rhythmic patterns in the surf zone. J. Geophys. Res..

Froidefond, J.-M., Gallissaires, J.M., 1990. Prud'homme, Spatial variation in sinusoidal wave energy on a crescentic nearshore bar; application to the Cap Ferret coast, France. J. Coastal Res. 6, 927-942. 
Gordon, H.R., Clark, D.K., 1980. Atmospheric effects in the remote sensing of phytoplankton pigments. Boundary Layer Meteorol. 18, 299-313.

King, C.A.M., Williams, W.E., 1949. The formation and movement of sand bars by wave action. Geogr. J. 113, 70-85.

Krabill, W., Wright, W., Swift, R., Frederick, E., Manizade, S., Yungel, J., Martin, C., Sonntag, J., Duffy, M., Hulsander, R., 2000. Airborne laser mapping of Assateague National Seashore Beach. Photogram. Eng. Remote Sens. 66, 65-71.

Lafon, V., 1999. Méthodes de bathymétrie satellitale appliquées à l'environnement côtier: exemple des passes d'Arcachon. Thèse de Doctorat, Université Bordeaux I, Talence, France.

Lafon, V., Froidefond, J.-M., Castaing, P., 2000. Méthode d'analyse de l'évolution morphodynamique d'une embouchure tidale par imagerie satellite. Exemple: le Bassin d'Arcachon (France). C. R. Acad. Sci. Ser. II 331, 373-378.

Lafon, V., Froidefond, J.-M., Lahet, F., Castaing, P., in press. SPOT shallow water bathymetry of a moderately turbid tidal inlet based on field measurements. Remote Sens. Environ..

Lau, J., Travis, B., 1973. Slowly varying Stokes waves and submarine longshore bars. J. Geophys. Res. 78, 4489-4497.

Lee, Z., Carder, K.L., Mobley, C.D., Steward, R.G., Patch, J.S., 1998. Hyperspectral remote sensing for shallow waters. I. A semianalytical model. Appl. Opt. 37, 6329-6338.

Loubersac, L., Dahl, A.L., Collotte, P., Lemaire, O., D’Ozouville, L., Grotte, A., 1988. Impact assessment of cyclone Sally on the almost atoll of Aitutaki (Cook islands) by remote sensing. Proceedings of the 6th International Coral Reef Symposium, Australia, Vol. 2. pp. $455-462$.
Lyzenga, D.R., 1978. Passive remote sensing techniques for mapping water depth and bottom features. Appl. Opt. 17, 379-383.

Michel, D., Howa, H., 1994. Morphological evolution of a littoral sandy bank, modelisation of its dynamics. An. Geophys. Eur. Geophys. Union Part II 12, 240.

Michel, D., Howa, H., 1999. Short-term morphodynamic response of a ridge and runnel system on a mesotidal sandy beach. J. Coastal Res. $15,428-437$.

Mulrennan, M.E., 1992. Ridge and runnel beach morphodynamics: an example from the Central East Coast of Ireland. J. Coastal Res. 8, 906-918.

O'Hare, T.J., Huntley, D.A., 1994. Bar formation due to wave groups and associated long waves. Mar. Geol. 116, 313-325.

Orford, J.D., Wright, P., 1978. What's is a name? Descriptive or genetic implications of a ridge and runnel topography. Mar. Geol. 28, M1-M8.

Owens, E.H., Frobel, D.H., 1977. Ridge and runnel systems in the Magdalen Islands, Quebec. J. Sediment. Petrol. 47, 191-198.

Pedreros, R., Howa, H., Michel, D., 1996. Application of grain-size-trend analysis for the determination of sediment transport pathways in intertidal areas. Mar. Geol. 135, 35-49.

Short, A.D., 1991. Macro-tidal beach morphodynamics-an overview. J. Coastal Res. 7, 417-436.

Vermote, E., Tanré, D., Deuzé, J.L., Herman, M., Morcrette, J.J., 1997. Second simulation of the satellite signal in the solar spectrum: an overview. IEEE Trans. Geosci. Remote Sens. 35, 675-686.

Viollier, M., Tanré, D., Deschamp, P.Y., 1980. An algorithm for remote sensing of water color from space. Boundary Layer Meteorol. 18, 247-267. 